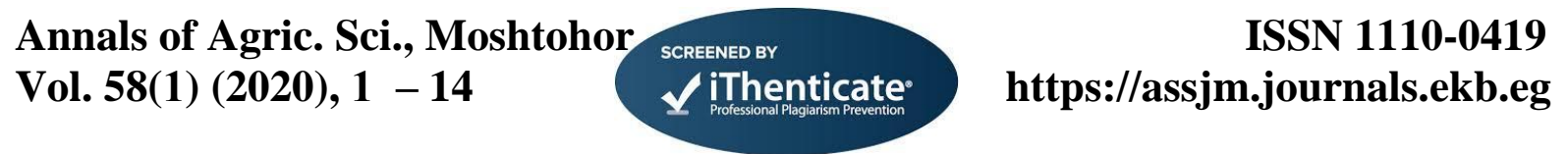

\title{
Effect of Planting Distances and Weed Control Treatments on Faba Bean Yield and Associated Weeds
}

\author{
El-Saeed M. M. El-Gedwy* A. M. Fadl-Allah ${ }^{* *}$ and A. M. A. Hassanein** \\ * Agronomy Department, Faculty of Agriculture, Benha University, Egypt \\ ** Weed Research Central Laboratory, Agricultural Research Center, Giza, Egypt.
}

Corresponding author: alsaeed.algedwy@fagr.bu.edu.eg

\begin{abstract}
Two field experiments were carried out in the Farm of Agricultural Research and Experimental Center of Agriculture Faculty at Moshtohor, Benha University, Qalyubia Governorate, Egypt, during 2017/18 and 2018/19 seasons. The study were investigated the effect of three planting distances, i.e. 20,25 and $30 \mathrm{~cm}$ between hills with six weed control treatments, i.e. acetochlor at rate of $840 \mathrm{~g}$ active ingredient (a.i)/fed (Harness $84 \% \mathrm{EC}$ ), pendimethalin at rate of $773.5 \mathrm{~g}$ a.i/fed (Stomp extra $45.5 \% \mathrm{CS}$ ), metribuzin at rate of $210 \mathrm{~g}$ a.i/fed (Sencor 70 $\% \mathrm{WP}$ ), bentazon at rate of $240 \mathrm{~g}$ a.i/fed (Basagran $48 \% \mathrm{AS}$ ) + clethodium at rate of $62.5 \mathrm{~g}$ a.i/fed (Select super $12.5 \%$ EC), hand hoeing twice and the unweeded check on growth, seed yield/fed and its yield components of faba bean $c v$. Giza 843 as well as associated weeds. Faba bean planted at narrow planting distance $(20 \mathrm{~cm}$ between hills) gave the lowest values of weed biomass compared with the other two planting distances (25 and $30 \mathrm{~cm}$ between hills) at 70 days after sowing as well as produced the greatest values of leaf area index, plant height and seed yield/fed during the both seasons. While, the highest values of No. of branches, No. of pods, No. of seeds and seed weight/plant as well as 100-seed weight were obtained from planting faba bean at wide planting distance $(30 \mathrm{~cm}$ between hills) in the both seasons. The main findings show that experimental field was infested by annual weeds for the unweeded check by 659.9 and $1041.8 \mathrm{~kg}$ dry weight of weeds/fed, exhibited seed yield loss of 74.82 and $79.65 \%$ faba bean yield/fed compared with the best treatment (hand hoeing twice) in 2017/2018 and 2018/2019 seasons, respectively, planting faba bean under hand hoeing twice or using bentazon + clethodium surpassed the other weed control treatments in depressing weed biomass at 70 days after faba bean sowing. On the other hand, the two treatments gave the greatest values of all faba bean traits without significant difference between them. The highest depression in weed biomass and the maximum values of plant height and seed yield/fed were recorded from planting faba bean at $20 \mathrm{~cm}$ between hills and weed control by hand hoeing twice or using bentazon + clethodium. While, the greatest values of No. of pods/plant, No. of seeds/plant and seed weight/plant in both seasons which obtained from planting faba bean at wide planting distance $(30 \mathrm{~cm}$ between hills) under weed control by hand hoeing twice or using bentazon + clethodium. Analyzing the faba bean seeds found that there was no residual detected of herbicides used. The economic analysis indicate that planting faba bean at $20 \mathrm{~cm}$ between hills and weed control by hand hoeing twice gave the net benefit valued 10435 and 8465 L.E./fed in the first and second seasons, respectively without herbicides residues. It could be summarized that planting faba bean $c v$. Giza 843 at planting distance $20 \mathrm{~cm}$ between hills with using hand hoeing twice or chemical control by bentazon + clethodium depression weed biomass and maximized seed yield/fed accompanied with the highest values of gross income, net benefit and benefit/cost and without herbicides residues.
\end{abstract}

Keywords: Faba bean - planting distances- weed control - herbicides - residual effect- Economic evaluation

\section{Introduction}

Faba bean (Vicia faba L.) is one of the most important legume crops for human consumption in Egypt as a protein source. It plays an essential role in enhancing soil fertility. Also, production of faba bean is still limited and falls to face the increasing local consumption especially, the low cultivated area, which decreased dramatically in last decades due to the strong competition between faba bean and other strategic winter crops such as wheat and clover in Nile valley, Delta and Upper Egypt. Furthermore is affected by different factors such as planting distances, weeds competition and pest attack.

Planting faba bean at wide distance between plants may result in low yield/unit area by leaving free spaces to more weed infestation (Alizadeh $\boldsymbol{e t} \boldsymbol{a l}$. 2014 and El-Metwally et al. 2017) and poor lightuse efficiency. However, narrow distance between plants can cause lodging, less light penetration in the crop canopy, reduced photosynthetic efficiency and consequently seed yield reduction. Many studies on the effect of planting distances on faba bean traits were conducted by various researchers such as (Dahmardeh et al 2010; Bakry et al. 2011; Khalil et al. 2011; Al-Suhaibani et al. 2013; Yucel 2013; Abd El-Rahman 2014; Derogar and Mojaddam 2014; Abou-El-Seba et al. 2016 and El-Metwally et al. 2017), they indicate that with increases in planting distances increased No. of branches, No. of pods, No. of seeds and seed weight/plant as well as 100-seed 
weight. Meanwhile, leaf area index, plant height and seed yield/fed were significantly decreased.

Weeds are considered a major problem in faba bean crop causing great losses in seed yield due to direct competed for environmental factors such as light, space and nutrients (Kavurmaci et al. 2010). Unrestricted weed growth and delayed weeding reduced seed yield of faba bean up to $46 \%$. So, weed control in the critical time for weed removal until 45 days after sowing. If the weed control is delayed further than the indicated stages, the yield losses would be much higher, especially under drought conditions and higher weed densities. Several investigators show that weed control by acetachlor and /or pendimethalin herbicides (El-Metwally and Dawood 2016 and Alemu and Sharma 2018), metribuzin herbicides (Abd El-Razik 2006; and ElMetwally et al. 2017), bentazon + clethodium herbicides (Aldhahi et al. 2018 and Fakkar and Khlifa 2018) and hand hoeing twice (Alizadeh $\boldsymbol{e t}$ al. 2014; Alemu and Sharma 2018 and Fakkar and Khlifa 2018) were significantly depressed dry weight of weeds compared to the unweeded check and then increased all faba bean yield and its components. In Egypt, until now there are no herbicides were recommended for weed control in faba bean.

So, this study aimed to investigate the effect of planting distances and weed control treatments on productivity of faba bean $c v$. Giza 843 and associated annual weeds.

\section{Materials and Methods}

Two field experiments were conducted in the Farm of Agricultural Research and the Experimental Center of Faculty of Agriculture at Moshtohor, Benha Univ., Qalyubia Governorate, Egypt, during 2017/18 and 2018/19 seasons. Each experiment included eighteen treatments which were the combinations between three distances between hills and six weed control treatments. The treatments in each experiment were arranged in a split plot design with four replications. The three planting distances were arranged at random in the main plots and the six weed control treatments were assigned at random in the sub plots, as follows:

\section{A. Planting distances:}

1) $20 \mathrm{~cm}$ distance between hills on both sides of the ridges with 2 plants/hill (140000 faba bean plants/fed).

2) $25 \mathrm{~cm}$ distance between hills on both sides of the ridges with 2 plants/hill (112000 faba bean plants/fed).

3) $30 \mathrm{~cm}$ distance between hills on both sides of the ridges with 2 plants/hill (93333 faba bean plants/fed).

\section{B. Weed control treatments:}

1) Acetochlor (Harness $84 \%$ EC): 2-chloro-N(ethoxymethyl)-N-(2-ethyl-6-methylphenyl) acetamide, applied as post sowing and before planting irrigation at rate of $840 \mathrm{~g}$ active ingredient (a.i)/fed.

2) Pendimethalin (Stomp extra $45.5 \% \mathrm{CS}$ ): N- (1ethylpropyl) -3,4- dimethyl -2,6- dinitro benzenamine, applied as post sowing and before planting irrigation at rate of $773.5 \mathrm{~g} \mathrm{a.i} / \mathrm{fed}$

3) Metribuzin (Sencor $70 \%$ WP): 4-amino-6-(1,1dimethylethyl) -3- (methylthio) -1,2,4-triazin$5(4 \mathrm{H})$-one, applied as post sowing and before planting irrigation at rate of $210 \mathrm{~g}$ a.i/fed.

4) Bentazon (Basagran $48 \%$ AS): 3-(1methylethyl)-(1H)-2,1,3-benzothiadiazin-4(3H)one 2,2-dioxide, applied as post emergence at 25 days after sowing at rate of $240 \mathrm{~g}$ a.i/fed + clethodium (Select super $12.5 \%$ EC): (E,E) -(6)2- [1- [[(3- chloro - 2 -propenyl)oxy]imino] propyl]-5-[2-(ethylthio) propyl] -3-hydroxy -2cyclohexen -1- one, applied as post emergence at 32 days after sowing at rate of $62.5 \mathrm{~g}$ a.i/fed.

5) Hand hoeing twice: at 21 and 45 days after sowing.

6) Unweeded check.

All herbicides were sprayed with volume of 200 liters water/fed. Seeds of faba bean cultivar $c v$. Giza 843 were obtained from Food Legumes Research Department, Field Crops Research Institute, Agricultural Research Center, Giza, Egypt. Faba bean seeds were inoculated with Rhizobium leguminosarum before planting on November 7 and 6 and thinned to double plants/hill before the first irrigation during 2017 and 2018 seasons, respectively. The preceding crop was maize in both seasons. The sub plot area was $12.6 \mathrm{~m}^{2}$ and contained seven ridges of $3 \mathrm{~m}$ length and $60 \mathrm{~cm}$ apart. Phosphorous fertilizer was applied in form of calcium super phosphate $\left(12.5 \% \mathrm{P}_{2} \mathrm{O}_{5}\right)$ at a rate of $200 \mathrm{~kg} / \mathrm{fed}$ during soil preparation in each season. Nitrogen fertilizer was applied in form of urea $(46 \% \mathrm{~N})$, according to the recommended rate $20 \mathrm{~kg} \mathrm{~N} / \mathrm{fed}$ at one dose before the first irrigation in each season. The normal cultural practices for growing faba bean plants were done as recommended.

Soil texture of the experimental sites was clay of $\mathrm{pH}$ nearly of 8.15 . The chemical and mechanical properties analysis of the experimental soil were determined according to the standard procedures described by Black and Evans (1965) and presented in Table (1). 
Table 1. Chemical and mechanical properties of the experimental soil units before planting faba bean during 2017/18 and 2018/19 seasons.

\begin{tabular}{|c|c|c|}
\hline \multirow{2}{*}{ Properties } & \multicolumn{2}{|c|}{ Season } \\
\hline & $2017 / 18$ & 2018/19 \\
\hline \multicolumn{3}{|l|}{ Chemical analysis } \\
\hline E.C. & 2.19 & 2.21 \\
\hline $\mathrm{pH}(1: 2.5)$ & 8.15 & 8.13 \\
\hline $\mathrm{CaCo}_{3} \%$ & 3.51 & 3.00 \\
\hline O.M \% & 2.16 & 2.23 \\
\hline $\mathrm{N} \%$ (total) & 0.170 & 0.173 \\
\hline $\mathrm{N}(\mathrm{ppm})$ (available) & 52.08 & 53.64 \\
\hline $\mathrm{P} \%$ (total) & 0.110 & 0.115 \\
\hline P (ppm) (available) & 19.5 & 20.67 \\
\hline $\mathrm{K} \%$ (total) & 0.61 & 0.62 \\
\hline $\mathrm{K}$ (ppm) (available) & 939.78 & 997.34 \\
\hline \multicolumn{3}{|c|}{ Soluble cations and anions $(\mathrm{ppm})$ or $\left(\mathrm{mmoL}_{\mathrm{e}} \mathbf{L}^{-1}\right)$} \\
\hline $\mathrm{Ca}^{++}$ & $186.6(9.33)$ & $191.6(9.58)$ \\
\hline $\mathrm{Mg}^{++}$ & $41.04(3.42)$ & $42.84(3.57)$ \\
\hline $\mathrm{K}^{+}$ & $45.63(1.17)$ & $46.80(1.20)$ \\
\hline $\mathrm{Na}^{+}$ & $190.44(8.28)$ & $192.28(8.36)$ \\
\hline $\mathrm{Cl}^{-}$ & $221.88(6.25)$ & $250.28(7.05)$ \\
\hline $\mathrm{Co}_{3}^{--}$ & 0.00 & 0.00 \\
\hline $\mathrm{H} \mathrm{Co}_{3}^{-}$ & $346.48(5.68)$ & $364.17(5.97)$ \\
\hline $\mathrm{So}_{4}^{--}$ & $492.96(10.27)$ & $465.12(9.69)$ \\
\hline \multicolumn{3}{|c|}{ Particle size distribution (mechanical analysis) } \\
\hline Course sand \% & 7.26 & 6.59 \\
\hline Find sand $\%$ & 26.91 & 27.64 \\
\hline Silt $\%$ & 13.85 & 12.60 \\
\hline Clay $\%$ & 51.98 & 53.17 \\
\hline Texture grade & Clay & Clay \\
\hline
\end{tabular}

\section{Data recorded:-}

\section{A. Weed measurements:-}

Weeds were manually pulled in a central area of one square meter area randomly placed from each sub plot after 70 days from sowing of faba bean in each season, identified and classified into annual broad-leaved and annual grassy weeds, then dried on an airforced drying oven at $70^{\circ} \mathrm{c}$ for $72 \mathrm{~h}$., and dry weights of weeds were recorded in $\mathrm{g} / \mathrm{m}^{2}$. The annual weeds existing in the experimental plots during the two seasons are presented in Table (2).

Table 2. The dominant annual weeds species in faba bean during 2017/18 and 2018/19 seasons.

\begin{tabular}{lll}
\hline & English name & \multicolumn{1}{c}{ Scientific name } \\
\hline Broadleaf weeds & & \\
& wild beet & Beta vulgaris, $\mathrm{L}$. \\
& bishop's weed & Ammi majus, L. \\
& bur clover & Medicago hispida, Gaertn \\
& sun spurge & Euphorbia helioscopia, $\mathrm{L}$. \\
& wild mustard & Brassica nigra,, L.) Kock \\
& fat hen & Chenopodium album, $\mathrm{L}$. \\
& scarlet pimpernel & Anagallis arvensis, $\mathrm{L}$. \\
& swine cress & Coronopus squamatus (Forrskål) Ascherson \\
\hline Grassy weeds & & \\
& wild oat & Avena fatua, L. \\
& canary grass & Phalaris minor, Retz. \\
\hline
\end{tabular}




\section{B. Faba bean characters:-}

At $50 \%$ podding stage, leaf area index were recorded as an average of five random plants from each sub-plot, as described by Roads and Bloodwoath (1964). At harvest, sample of ten guarded plants were taken at random to determine plant height $(\mathrm{cm})$, No. of branches, No. of pods, No. of seeds and seed weight/plant $(\mathrm{g})$ as well as 100seed weight $(\mathrm{g})$. While, seed yields/fed $(\mathrm{kg})$ were calculated from the three middle ridges of each plots.

\section{C - Herbicide residues in faba bean seeds.}

In the second season, the herbicides residues for acetochlor (Harness), pendimethalin (Stomp extra), metribuzin (Sencor), bentazon (Basagran) and clethodium (Select super) in faba bean seeds were analyzed by using the Gas Liquid Chromatography method according to Nguyen et al. (2008) in Central Agri. Pesticides Lab. A.R.C., Dokki, Giza, Egypt.

\section{D - Economic evaluation.}

Economic evaluation due to weed control treatments was calculated according to Heady and Dillon (1961) as follows:

Gross income (L.E.) = yield (ton/fed) $\mathrm{x}$ price of ton (L.E.). Gross margin (L.E.) = gross income - total cost (L.E.).

Benefit/cost ratio $=$ gross income/total cost.

\section{Statistical analysis:}

The analysis of variance was carried out according to the procedure described by Gomez and Gomez (1984), and using the MSTAT-C Statistical Software Package (Freed, 1991).The least significant differences (L.S.D.) test at $5 \%$ level was used to compare the treatments mean.

\section{Results and Discussion}

\section{A- Weed measurements:-}

The annual weeds presented in the experimental plots during the two seasons were wild beet (Beta vulgaris, L.), bishop's weed (Ammi majus, L.), bur clover (Medicago hispida, Gaertn), sun spurge (Euphorbia helioscopia, L.), wild mustard (Brassica nigra, (L.) Kock), fat hen (Chenopodium album, L.), scarlet pimpernel (Anagallis arvensis, L.) and swine cress (Coronopus squamatus (Forrskål) Ascherson as broad leaf weeds with infestation rates 425.4 and $656.6 \mathrm{~kg}$ dry weight/fed in the first and second seasons, respectively, while, wild oat (Avena fatua, L.) and canary grass (Phalaris minor, Retz.) as grassy weeds with infestations rates 234.5 and $385.2 \mathrm{~kg}$ dry weight/fed in both seasons, respectively (Table 3 ). Wild beet, wild oat, bishop's weed and bur clover were prevalent weeds, while the other annual weeds were less existing.

\section{1- Effect of planting distances:-}

Dry weights of annual broad-leaved, grassy and total weeds at 70 days after sowing were significantly increased with increasing in planting distances up to $30 \mathrm{~cm}$ in both seasons (Table 3). No significance differences were shown between planting distance of 25 and $20 \mathrm{~cm}$ on dry weight of annual broad-leaved weeds in both seasons as well as between planting distances of 30 and $25 \mathrm{~cm}$ on dry weight of annual grassy weeds in the second seasons. The greatest reduction in weed biomass was achieved by sowing faba bean at $20 \mathrm{~cm}$ between hills, where it decreased dry weight of annual broad-leaved weeds reached to (16.43\% and $14.44 \%$ ), annual grassy weeds (28.82 $\%$ and $12.06 \%)$ and total annual weeds $(20.63 \%$ and $13.61 \%$ ) compared with planting faba bean at $30 \mathrm{~cm}$ between hills in the first and second seasons, respectively. The gradual depression in weed biomass at narrow distance between hills may be due to no leaving free spaces to more weed infestation as well as increased inter-specific competition between faba bean plants and weeds for environmental factors. These results are in agreement with those reported by Alizadeh et al. 2014 and El-Metwally et al. 2017.

\section{2- Effect of weed control treatments:-}

Results in Table 3 indicate that, all weed control treatments significantly decreased the dry weight of the two categories of weeds at 70 days after sowing compared to the unweeded check in both seasons. Hand hoeing twice was the best treatment on reducing the dry weight of annual broad-leaved weeds by $97.80 \%$ and $94.60 \%$; annual grassy weeds by $95.59 \%$ and $93.52 \%$ as well as total annual weeds by $97.02 \%$ and $94.20 \%$, followed by bentazon $240 \mathrm{~g}$ a.i/fed + clethodium $62.5 \mathrm{~g}$ a.i/fed herbicides by $91.50 \& 92.30 \% ; 94.73 \& 91.90 \%$ and $92.65 \& 92.15 \%$ without significant different between them compared with unweeded check in both seasons, respectively. The following treatments on reducing dry weight of annual broad-leaved weeds were acetochlor, metribuzin and pendimethalin in both seasons respectively; on dry weight of annual grassy weeds were pendimethalin, metribuzin and acetachlor in both seasons respectively; and on dry weight of the total annual weeds were acetachlor, metribuzin and pendimethalin respectively, in the first season and were metribuzin, acetachlor and pendimethalin respectively, in the second season. No significantly difference was shown between bentazon + clethodium and hand hoeing twice as well as among metribuzin and acetochlor on all weeds measurements under study in both seasons. Similar results were obtained by Abd El-Razik 2006; Agegnehu and Fessehaie 2006; El-Metwally and Abdel hamid 2008; El-Metwally 2016; ElMetwally and Dawood 2016; El-Metwally et al., 2017; Aldhahi et al., 2018; Alemu and Sharma, 2018 and Fakkar and Khlifa 2018, they found that weed control by hand hoeing twice or herbicides were significantly depressed dry weight of weeds compared to the unweeded check. 
Table 3. Effect of planting distances and weed control treatments on dry weight of annual weeds $\left(\mathrm{g} / \mathrm{m}^{2}\right)$ at 70 days from sowing faba bean during 2017/18 and 2018/19 seasons.

\begin{tabular}{|c|c|c|c|c|c|c|}
\hline \multirow{2}{*}{ Treatment } & \multicolumn{6}{|c|}{ Dry weight $\left(\mathrm{g} / \mathrm{m}^{2}\right)$} \\
\hline & \multicolumn{2}{|c|}{ Broad-leaved weeds } & \multicolumn{2}{|c|}{ Grassy weeds } & \multicolumn{2}{|c|}{ Total weeds } \\
\hline Season & $2017 / 18$ & 2018/19 & $2017 / 18$ & 2018/19 & 2017/18 & 2018/19 \\
\hline \multicolumn{7}{|l|}{ Planting distance } \\
\hline $20 \mathrm{~cm}$ & 26.40 & 44.07 & 11.61 & 24.58 & 38.01 & 68.64 \\
\hline $25 \mathrm{~cm}$ & 28.09 & 46.92 & 14.34 & 26.52 & 42.43 & 73.44 \\
\hline $30 \mathrm{~cm}$ & 31.59 & 51.51 & 16.31 & 27.95 & 47.89 & 79.45 \\
\hline L.S.D at 5\% & 3.11 & 3.32 & 1.21 & 1.82 & 3.92 & 4.11 \\
\hline \multicolumn{7}{|l|}{ Weed control treatment $(\mathrm{g}$ a.i/fed) } \\
\hline Acetochlor $840 \mathrm{~g}$ & 13.24 & 23.37 & 9.96 & 23.06 & 23.20 & 46.43 \\
\hline Pendimethalin $773 \mathrm{~g}$ & 31.33 & 57.94 & 5.55 & 11.32 & 36.88 & 69.26 \\
\hline Metribuzin $210 \mathrm{~g}$ & 15.43 & 26.85 & 7.78 & 18.61 & 23.21 & 45.47 \\
\hline Bentazon $240 \mathrm{~g}+$ Clethodium $62.5 \mathrm{~g}$ & 8.61 & 12.04 & 2.94 & 7.43 & 11.55 & 19.47 \\
\hline Hand hoeing twice & 2.23 & 8.45 & 2.46 & 5.94 & 4.69 & 14.39 \\
\hline Unweeded check & 101.29 & 156.34 & 55.83 & 91.71 & 157.12 & 248.05 \\
\hline L.S.D at 5\% & 6.45 & 11.32 & 2.63 & 3.97 & 8.37 & 14.35 \\
\hline
\end{tabular}

\section{B- Faba bean characters:-}

\section{1- Effect of planting distances:-}

Results presented in Table 4 revealed that the differences between the studied three planting distances, i.e. 30,25 and $20 \mathrm{~cm}$ were significant on most growth characteristics, seed yield/fed and its components and during 2017/18 and 2018/19 seasons. Data revealed that planting faba bean at 20 $\mathrm{cm}$ between hills gave the greatest values of leaf area index (4.48 and 4.07), plant height (106.3 and 101.7 $\mathrm{cm})$ and seed yield/fed (713.90 and $579.33 \mathrm{~kg}$ ), in both seasons, respectively. Planting faba bean at 20 $\mathrm{cm}$ between hills increased seed yield/fed by 4.20 and $14.47 \%$ in the first season and 5.26 and $16.76 \%$, in the second season compared with the growing at 25 and $30 \mathrm{~cm}$ between hills respectively. The increases in value of plant height at narrow planting distance $(20 \mathrm{~cm})$ is mainly due to increase intra-specific competition among faba bean plants for light penetration, interception and photosynthetic efficiency as well as higher dense of plants excessive shade exist which help to produce more content of gibberellin in tissues and consequently higher plants formed. The greatest values of No. of branches/plant (3.63 and 3.12 branches), No. of pods/plant (16.67 and 14.57 pods), No. of seeds/plant (28.28 and 27.17 seeds), seed weight/plant (17.12 and $16.23 \mathrm{~g})$ and 100 -seed weight $(60.88$ and $61.83 \mathrm{~g})$ in the first and second seasons, respectively were obtained from planting faba bean at wide distance between hills (30 $\mathrm{cm}$ ). This trend could be explained on the fact that in case of wide distance between hills resulted in low competition between faba bean plants for nutrient elements, soil moisture and sun light, plants would have better opportunity to produce more metabolite contents and positive effect on plant growth and productivity as well as increased translocation and consequently accumulation of metabolites through seeds and gave the maximum values of plant traits and yield components. No. significance differences were shown among planting faba bean at 20 and 25 $\mathrm{cm}$ between hills. Many investigators obtained similar results as Badran and Ahmed 2010; Dahmardeh et al. 2010; Bakry et al. 2011; Khalil et al. 2011; Al-Suhaibani et al. 2013; Yucel 2013; Abd El-Rahman 2014; Derogar and Mojaddam 2014; Abou-El-Seba et al. 2016 and El-Metwally et al. 2017.

\section{2- Effect of weed control treatments:-}

All weed control treatments caused significant increasing in studied growth traits at podding stage, seed yield/fed and its components of faba bean in both seasons as presented in Table 4. Hand hoeing twice gave the highest increasing percentage of No. of pods/plant by $115.60 \& 118.51 \%$; No. of seeds/plant by $164.96 \& 186.48 \%$; seed weight/plant by $193.91 \& 273.18 \%$; 100 -seed weight $(\mathrm{g})$ by 25.11 \& $43.03 \%$ and seed yield/fed by 297.18 \& $391.45 \%$ compared to unweeded check in both seasons, respectively. Meanwhile, bentazon $240 \mathrm{~g}$ a.i/fed + clethodium $62.5 \mathrm{~g}$ a.i/fed treatment was superiored hand hoeing for leaf area index, plant height $(\mathrm{cm})$ and No. of branches/plant and the next treatment increased leaf area index by $79.03 \& 80.43 \%$; plant height by $34.98 \& 36.46$; No. of branches/plant by $129.44 \& 138.00 ;$ No. of pods/plant by 103.51 \&111.76\%; No. of seeds/plant by $140.24 \& 154.88$ $\%$; seed weight/plant by $175.65 \& 258.63 \%$; 100 seed weight $(\mathrm{g})$ by $23.86 \& 41.54 \%$ and seed yield/fed by $285.57 \& 370.66 \%$ compared to 
unweeded check in both seasons, respectively. The following herbicidal treatments effect on increasing the plant growth and seed yield/fed of faba bean characteristics were in a descending order: acetachlor, metribuzin and pendimethalin for plant height, No. of seeds/plant and seed yield/fed in the both seasons, leaf area index and weight of seeds/plant in the second seasons as well as No. of pods/plant in the first season. Meanwhile, metribuzin, acetachlor and pendimethalin for No. of branches/plant and 100-seed weight in seasons, leaf area index and weight of seeds/plant in the first seasons as well as No. of pods/plant in the second season. No significantly difference was shown between bentazon + clethodium and hand hoeing twice as well as among metribuzin and acetochlor on all faba bean characters under study in both seasons. The increases in seed yield/fed may be due to the good role of hand hoeing and the best herbicides treatments in improving and increasing yield attributes, i.e. No. of branches/plant, No. of pods/plant, No. of seeds/plant and seed yield/plant. These results are in harmony with those reported by Abd El-Razik 2006; Agegnehu and Fessehaie 2006; El-Metwally and Abdelhamid 2008; ElMetwally 2016; El-Metwally and Dawood 2016; El-Metwally et al., 2017; Aldhahi et al., 2018; Alemu and Sharma, 2018 and Fakkar and Khlifa 2018, who found that seed yield of faba bean and some yield components characters were increased as a result of using hand hoeing twice or some herbicidal treatments as bentazon + clethodium.

Table 4. Effect of planting distances and weed control treatments on growth, seed yield/fed and its components of faba bean during 2017/18 and 2018/19 seasons.

\begin{tabular}{|c|c|c|c|c|c|c|c|c|}
\hline Treatment Character & $\begin{array}{c}\text { Leaf } \\
\text { area } \\
\text { index } \\
\end{array}$ & $\begin{array}{c}\text { Plant } \\
\text { height } \\
(\mathrm{cm})\end{array}$ & $\begin{array}{c}\text { No. of } \\
\text { branches } \\
\text { /plant }\end{array}$ & $\begin{array}{l}\text { No. of } \\
\text { pods } \\
\text { /plant }\end{array}$ & $\begin{array}{l}\text { No. of } \\
\text { seeds } \\
\text { /plant } \\
\end{array}$ & $\begin{array}{c}\text { Seed } \\
\text { weight } \\
\text { /plant (g) }\end{array}$ & $\begin{array}{c}\text { 100-seed } \\
\text { weight } \\
(\mathrm{g}) \\
\end{array}$ & $\begin{array}{c}\text { Seed } \\
\text { yield/fed } \\
(\mathrm{kg})\end{array}$ \\
\hline Planting distance & \multicolumn{8}{|c|}{ 2017/18 season } \\
\hline $20 \mathrm{~cm}$ & 4.48 & 106.3 & 2.95 & 12.07 & 21.43 & 12.26 & 56.57 & 713.90 \\
\hline $25 \mathrm{~cm}$ & 4.12 & 101.5 & 3.28 & 14.75 & 25.73 & 15.03 & 59.26 & 685.13 \\
\hline $30 \mathrm{~cm}$ & 3.70 & 96.3 & 3.63 & 16.67 & 28.28 & 17.12 & 60.88 & 623.67 \\
\hline \multirow[t]{2}{*}{ L.S.D at $5 \%$} & 0.25 & 3.3 & 0.31 & 1.31 & 2.41 & 2.25 & 2.68 & 65.14 \\
\hline & \multicolumn{8}{|c|}{ 2018/19 season } \\
\hline $20 \mathrm{~cm}$ & 4.07 & 101.7 & 2.53 & 10.40 & 17.95 & 10.42 & 57.71 & 579.33 \\
\hline $25 \mathrm{~cm}$ & 3.67 & 96.6 & 2.85 & 12.78 & 23.73 & 13.53 & 60.14 & 550.37 \\
\hline $30 \mathrm{~cm}$ & 3.28 & 90.5 & 3.12 & 14.57 & 27.17 & 16.23 & 61.83 & 496.18 \\
\hline L.S.D at $5 \%$ & 0.26 & 3.7 & 0.29 & 1.12 & 2.56 & 2.05 & 2.73 & 51.36 \\
\hline Weed control treatment ( $\mathrm{g}$ a.i/fed) & \multicolumn{8}{|c|}{ 2017/18 season } \\
\hline Acetochlor $840 \mathrm{~g}$ & 4.35 & 106.5 & 3.47 & 16.13 & 26.63 & 15.75 & 59.84 & 714.30 \\
\hline Pendimethalin $773 \mathrm{~g}$ & 3.87 & 91.6 & 2.67 & 12.10 & 18.80 & 12.43 & 56.94 & 548.37 \\
\hline Metribuzin $210 \mathrm{~g}$ & 4.38 & 106.3 & 3.80 & 15.80 & 26.37 & 16.62 & 60.98 & 704.13 \\
\hline Bentazon $240 \mathrm{~g}+$ Clethodium $62.5 \mathrm{~g}$ & 4.78 & 112.3 & 4.13 & 16.83 & 31.40 & 18.11 & 62.35 & 907.90 \\
\hline Hand hoeing twice & 4.53 & 108.3 & 3.87 & 17.83 & 34.63 & 19.31 & 62.98 & 935.23 \\
\hline Unweeded check & 2.67 & 83.2 & 1.80 & 8.27 & 13.07 & 6.57 & 50.34 & 235.47 \\
\hline \multirow[t]{2}{*}{ L.S.D at $5 \%$} & 0.38 & 6.6 & 0.42 & 1.54 & 3.56 & 2.15 & 2.85 & 89.24 \\
\hline & \multicolumn{8}{|c|}{ 2018/19 season } \\
\hline Acetochlor $840 \mathrm{~g}$ & 3.99 & 101.5 & 3.07 & 13.57 & 25.73 & 15.43 & 63.07 & 610.70 \\
\hline Pendimethalin $773 \mathrm{~g}$ & 3.53 & 86.9 & 2.30 & 9.10 & 15.77 & 10.02 & 56.80 & 387.80 \\
\hline Metribuzin $210 \mathrm{~g}$ & 3.96 & 98.7 & 3.27 & 13.60 & 24.57 & 14.89 & 63.51 & 567.70 \\
\hline Bentazon $240 \mathrm{~g}+$ Clethodium $62.5 \mathrm{~g}$ & 4.15 & 107.8 & 3.57 & 15.67 & 28.47 & 17.25 & 64.77 & 746.93 \\
\hline Hand hoeing twice & 4.10 & 103.7 & 3.30 & 16.17 & 32.00 & 17.95 & 65.45 & 779.93 \\
\hline Unweeded check & 2.30 & 79.0 & 1.50 & 7.40 & 11.17 & 4.81 & 45.76 & 158.70 \\
\hline L.S.D at $5 \%$ & 0.31 & 5.9 & 0.37 & 1.51 & 3.11 & 1.99 & 3.11 & 80.45 \\
\hline
\end{tabular}




\section{3- Interaction effect between planting distances and weed control treatments:-}

\subsection{Weed measurements:-}

Results in Table $\mathbf{5}$ show a significant interaction effect between planting distances and weed control treatments on dry weights of annual broad-leaved, grassy and total weeds in 2017/18 and 2018/19 seasons at 70 days after sowing faba bean. Results indicate that planting faba bean at narrow distance between hills $(20 \mathrm{~cm})$ gave the greatest depression in all weed biomass under all weed control treatments. On the other hand, planting faba bean at wide distance between hills $(30 \mathrm{~cm})$ gave the lowest depression in all values with all weed control treatments in both growing seasons. Also, weed control in faba bean fields by hand hoeing twice or using bentazon + clethodium gave the greatest depression in all weed biomass under all planting distances in both seasons. The highest depression in dry weights of annual broad-leaved (1.88 and $7.95 \mathrm{~g})$, grassy (1.58 and $5.62 \mathrm{~g})$ and total weeds (3.46 and $13.57 \mathrm{~g}$ ) in the first and second seasons respectively, at 70 days after sowing faba bean was recorded from narrow distance between hills $(20 \mathrm{~cm})$ and treated with hand hoeing twice. These results are in agreement with those obtained by Sary et al. 1989; Ismail and Fakkar 2008; Alizadeh et al. 2014 and El-Metwally et al. 2017; Abou-El-Seba et al. 2016 and El-Metwally et al. 2017.

Table 5. Effect of the interaction between planting distances and weed control treatments on dry weight of annual weeds $\left(\mathrm{g} / \mathrm{m}^{2}\right)$ at 70 days from sowing faba bean in 2017/18 and 2018/19 seasons.

\begin{tabular}{llcccccc}
\hline \multirow{2}{*}{$\begin{array}{c}\text { Planting } \\
\text { distance }\end{array}$} & \multicolumn{1}{c}{$\begin{array}{c}\text { Weed control treatments } \\
\text { (g a.i/fed) }\end{array}$} & \multicolumn{2}{c}{$\begin{array}{c}\text { Broad-leaved } \\
\text { weeds }\end{array}$} & \multicolumn{2}{c}{ Grassy weeds } & \multicolumn{2}{c}{ Total weeds } \\
\cline { 2 - 7 } & & $\mathbf{2 0 1 7 / 1 8}$ & $\mathbf{2 0 1 8 / 1 9}$ & $\mathbf{2 0 1 7 / 1 8}$ & $\mathbf{2 0 1 8 / 1 9}$ & $\mathbf{2 0 1 7 / 1 8}$ & $\mathbf{2 0 1 8 / 1 9}$ \\
\hline \multirow{2}{*}{$20 \mathrm{~cm}$} & Acetochlor 840 g & 12.36 & 21.38 & 8.76 & 21.98 & 21.12 & 43.36 \\
& Pendimethalin 773 g & 28.64 & 55.59 & 4.43 & 10.26 & 33.07 & 65.85 \\
& Metribuzin 210 g & 13.63 & 25.65 & 6.95 & 17.35 & 20.58 & 43.00 \\
& Bentazon 240 g + Clethodium 62.5 g & 7.25 & 11.02 & 1.79 & 6.98 & 9.04 & 18.00 \\
& Hand hoeing twice & 1.88 & 7.95 & 1.58 & 5.62 & 3.46 & 13.57 \\
& Unweeded check & 94.62 & 142.82 & 46.15 & 85.26 & 140.77 & 228.08 \\
& Acetochlor 840 g & 12.74 & 23.09 & 9.85 & 22.86 & 22.59 & 45.95 \\
& Pendimethalin 773 g & 31.15 & 55.86 & 5.49 & 11.42 & 36.64 & 67.28 \\
& Metribuzin 210 g & 15.02 & 26.35 & 7.83 & 18.62 & 22.85 & 44.97 \\
& Bentazon 240 g + Clethodium 62.5 g & 9.04 & 11.87 & 3.15 & 7.27 & 12.19 & 19.14 \\
& Hand hoeing twice & 2.06 & 7.86 & 2.48 & 5.98 & 4.54 & 13.84 \\
& Unweeded check & 98.50 & 156.51 & 57.26 & 92.97 & 155.76 & 249.48 \\
& Acetochlor 840 g & 14.63 & 25.63 & 11.26 & 24.35 & 25.89 & 49.98 \\
& Pendimethalin 773 g & 34.21 & 62.37 & 6.72 & 12.29 & 40.93 & 74.66 \\
& Metribuzin 210 g & 17.65 & 28.56 & 8.56 & 19.87 & 26.21 & 48.43 \\
30 cm & Bentazon 240 g + Clethodium 62.5 g & 9.53 & 13.24 & 3.89 & 8.04 & 13.42 & 21.28 \\
& Hand hoeing twice & 2.76 & 9.54 & 3.32 & 6.23 & 6.08 & 15.77 \\
& Unweeded check & 110.75 & 169.70 & 64.08 & 96.89 & 174.83 & 266.59 \\
\hline L.S.D at 5\% & $\mathbf{1 5 . 8 0}$ & $\mathbf{2 7 . 7 3}$ & $\mathbf{6 . 4 4}$ & $\mathbf{9 . 7 2}$ & $\mathbf{2 0 . 5 0}$ & $\mathbf{3 5 . 1 5}$ \\
\hline
\end{tabular}

\subsection{Faba bean plant characters:-}

Results in Table 6 show that there were significant effect of the interaction between the three planting distances and the six weed control treatments on faba bean plant trails: plant height (cm), No. of pods/plant, No. of seeds/plant, seed weight/plant $(\mathrm{g})$ and seed yield/fed $(\mathrm{kg})$. That is true in both seasons. In the first season, the interaction amoung $20 \mathrm{~cm}$ between hills and either hand hoeing twice and/or bentazon $240 \mathrm{~g}$ a.i/fed + clethodium $62.5 \mathrm{~g}$ a.i/fed gave the highest increasing percentage for plant height $(43.07 \& 46.53 \%)$ and faba bean seed yield/fed (367.58 \& $339.82 \%)$, respectively compared with the interaction between unweed check with $30 \mathrm{~cm}$ between hills. Also, the interaction among $30 \mathrm{~cm}$ between hills and both the same previous treatments gave the highest increasing percentage for No. of pods/plant (181.08 \& 162.16 $\%$ ), No. of seeds/plant (273.79 \& $246.60 \%)$ and seed weight/plant (329.25 \& $306.98 \%)$ respectively, compared with the interaction among unweed check with $20 \mathrm{~cm}$ between hills. While, in the second season the interaction among $20 \mathrm{~cm}$ between hills and either hand hoeing twice and /or bentazon $240 \mathrm{~g}$ 
a.i/fed + clethodium $62.5 \mathrm{~g}$ a.i/fed gave the highest increasing percentage for plant height (47.09 \& $52.38 \%$ ) and faba bean seed yield/fed (547.99 \& $489.80 \%)$, respectively compared with the interaction among unweed check with $30 \mathrm{~cm}$ between hills. Also, the interaction among $30 \mathrm{~cm}$ between hills and both the same previous treatments gave the highest increasing percentage for No. of pods/plant (200.00 \& $187.69 \%$ ), No. of seeds/plant (336.05 \& $284.88 \%$ ) and seed weight/plant (454.64 \& 452.32 $\%)$ respectively, compared with the interaction among unweed check with $20 \mathrm{~cm}$ between hills (ElMetwally et al. 2017). Meanwhile, the interaction among $25 \mathrm{~cm}$ between hills and both the previous treatments were the second after the interaction among $20 \mathrm{~cm}$ between hills and both the previous treatments for the values of plant height (108.7 \& $112.9 \mathrm{~cm})$ and faba bean seed yield/fed $(935.5 \&$ $926.5 \mathrm{~kg}$ ), respectively and after the interaction among $30 \mathrm{~cm}$ between hills and both the previous treatments of the values of the rest previous plant characteristics. Also, there was no significant effect of the interaction between the three planting distances and all the six weed control treatments on leaf area index, No. of branches/plant and 100-seed weight.

Table 6. Effect of the interaction between planting distances and weed control treatments on values of growth, seed yield/fed and its components of faba bean during 2017/18 and 2018/19 seasons.

\begin{tabular}{|c|c|c|c|c|c|c|c|c|c|}
\hline & Character & $\begin{array}{l}\text { Leaf } \\
\text { area } \\
\text { index }\end{array}$ & $\begin{array}{c}\text { Plant } \\
\text { height } \\
(\mathrm{cm})\end{array}$ & $\begin{array}{l}\text { No. of } \\
\text { branches } \\
\text { /plant }\end{array}$ & $\begin{array}{c}\text { No. of } \\
\text { pods } \\
\text { /plant }\end{array}$ & $\begin{array}{l}\text { No. of } \\
\text { seeds } \\
\text { /plant }\end{array}$ & $\begin{array}{c}\text { Seed } \\
\text { weight } \\
\text { /plant } \\
\text { (g) }\end{array}$ & $\begin{array}{c}100- \\
\text { seed } \\
\text { weight } \\
(\mathrm{g})\end{array}$ & $\begin{array}{c}\text { Seed } \\
\text { yield } \\
\text { /fed } \\
(\mathrm{kg})\end{array}$ \\
\hline $\begin{array}{l}\text { Planting } \\
\text { distance }\end{array}$ & $\begin{array}{l}\text { Weed control treatment } \\
\text { (g a.i/fed) }\end{array}$ & & & & 201 & son & & & \\
\hline & Acetochlor $840 \mathrm{~g}$ & 4.69 & 110.5 & 3.2 & 13.5 & 23.4 & 13.89 & 58.25 & 764.5 \\
\hline & Pendimethalin $773 \mathrm{~g}$ & 4.32 & 94.5 & 2.4 & 10.2 & 16.8 & 10.21 & 54.61 & 571.8 \\
\hline & Metribuzin $210 \mathrm{~g}$ & 4.72 & 112.5 & 3.4 & 13.2 & 21.6 & 14.23 & 58.94 & 763.9 \\
\hline $20 \mathrm{~cm}$ & Bentazon $240 \mathrm{~g}+$ Clethodium $62.5 \mathrm{~g}$ & 5.23 & 118.4 & 3.7 & 13.6 & 26.3 & 14.03 & 60.19 & 933.3 \\
\hline & Hand hoeing twice & 4.97 & 115.6 & 3.5 & 14.5 & 30.2 & 15.87 & 60.50 & 992.2 \\
\hline & Unweeded check & 2.93 & 86.0 & 1.5 & 7.4 & 10.3 & 5.30 & 46.92 & 257.7 \\
\hline & Acetochlor $840 \mathrm{~g}$ & 4.45 & 106.3 & 3.5 & 16.2 & 26.8 & 15.44 & 59.73 & 752.3 \\
\hline & Pendimethalin $773 \mathrm{~g}$ & 3.77 & 92.1 & 2.6 & 12.3 & 18.9 & 12.88 & 57.65 & 544.0 \\
\hline & Metribuzin $210 \mathrm{~g}$ & 4.53 & 106.4 & 3.9 & 15.8 & 27.8 & 16.88 & 61.43 & 716.0 \\
\hline $25 \mathrm{~cm}$ & Bentazon $240 \mathrm{~g}+$ Clethodium $62.5 \mathrm{~g}$ & 4.79 & 112.9 & 4.1 & 17.5 & 32.2 & 18.73 & 62.97 & 926.5 \\
\hline & Hand hoeing twice & 4.52 & 108.7 & 3.8 & 18.2 & 35.2 & 19.32 & 63.54 & 935.5 \\
\hline & Unweeded check & 2.64 & & & 8.5 & 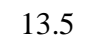 & 6.90 & 50.25 & 236.5 \\
\hline & Acetochlor & 392 & 102.7 & 3 & 18.7 & 20 & 17.93 & 61.54 & 626.1 \\
\hline & Pendimethalin $773 \mathrm{~g}$ & 3.51 & 88 & 3 & 13 & 20 & 14.21 & 58.55 & 529.3 \\
\hline $30 \mathrm{~cm}$ & Metribuzin $210 \mathrm{~g}$ & 3.88 & 100.1 & 4.1 & 18.4 & 29.7 & 18.76 & 62.57 & 632.5 \\
\hline $30 \mathrm{~cm}$ & Bentazon $240 \mathrm{~g}+$ Clethodiur & 4.32 & & 4.6 & 19.4 & 357 & 21.57 & 63.89 & 863.9 \\
\hline & Hand hoeing twice & 4.1 & 5 & 4. & 20.8 & 38 & 22.75 & 64.89 & 878.0 \\
\hline & Unweeded check & 2.44 & 80.8 & .1 & 8.9 & 15.4 & 7.52 & 53.86 & 212.2 \\
\hline L.S.D at 5 & $5 \%$ & N.S. & 16.2 & N.S. & 3.8 & 8.7 & 5.27 & N.S. & 218.6 \\
\hline & & & & & 201 & eason & & & \\
\hline & Acet & 4.28 & 106.5 & 2.8 & 11.5 & 20.5 & 11.99 & 60.45 & 665.2 \\
\hline & Pendimethalin $773 \mathrm{~g}$ & 4.01 & & 2.0 & & 11 & 7.31 & 53.60 & 406.5 \\
\hline $20 \mathrm{~cm}$ & Metribuzin $210 \mathrm{~g}$ & 4.32 & 104.2 & 3.0 & 11.2 & 18.7 & 11.58 & 61.52 & 624.4 \\
\hline $20 \mathrm{~cm}$ & Bentazon $240 \mathrm{~g}+$ Cletl & 4.65 & 115.2 & 3.2 & 12.4 & 22.5 & 12.99 & 63.76 & 763.2 \\
\hline & Hand hoeing twice & 4.62 & 111.2 & 3.0 & 12.6 & 25.9 & 14.78 & 64.25 & 838.5 \\
\hline & Unweeded check & 2.51 & 82.6 & 1.2 & 6.5 & 8.6 & 3.88 & 42.65 & 178.2 \\
\hline & Acetochlor $840 \mathrm{~g}$ & & 102.5 & & 13.8 & 26.6 & 15.87 & 63.77 & 636.5 \\
\hline & Pendimet & 3. & & & & 15.6 & 10.21 & 57.10 & 392.4 \\
\hline 25 & Metribuzin $210 \mathrm{~g}$ & 4.05 & 100.3 & 3.3 & 13.7 & 26.1 & 15.21 & 63.88 & 584.5 \\
\hline $25 \mathrm{~cm}$ & Bentazon $240 \mathrm{~g}+$ Clethod & 4.15 & 107.5 & 3.6 & 15.9 & 29.8 & 17.34 & 64.55 & 751.5 \\
\hline & Hand hoeing twice & 4.11 & & 3.2 & 16.4 & 32.6 & 17.56 & 65.88 & 768.8 \\
\hline & Unweeded check & 2.26 & 78.9 & 1.6 & 7.6 & 11.7 & 4.98 & 45.68 & 168.5 \\
\hline & Acetochlor $840 \mathrm{~g}$ & 3.55 & & 3.3 & 15.4 & 30.1 & 18.43 & 64.99 & 530.4 \\
\hline & Pendimethalin $773 \mathrm{~g}$ & 3.28 & 83.2 & 2.6 & 9.8 & 20.2 & 12.55 & 59.70 & 364.5 \\
\hline & Metribuzin $210 \mathrm{~g}$ & 3.52 & 91.5 & 3.5 & 15.9 & 28.9 & 17.87 & 65.12 & 494.2 \\
\hline 3 & Bentazon $240 \mathrm{~g}+$ Clethodium $62.5 \mathrm{~g}$ & 3.66 & 100.6 & 3.9 & 18.7 & 33.1 & 21.43 & 65.99 & 726.1 \\
\hline & Hand hoeing twice & 3.56 & 96.5 & 3.7 & 19.5 & 37.5 & 21.52 & 66.23 & 732.5 \\
\hline & Unweeded check & 2.12 & 75.6 & 1.7 & 8.1 & 13.2 & 5.57 & 48.96 & 129.4 \\
\hline L.S.D at 5 & $5 \%$ & N.S. & 14.5 & N.S. & 3.7 & 7.6 & 4.87 & N.S. & 197.1 \\
\hline
\end{tabular}


4- Correlation studies between studded traits: -

Table (7) show that the correlation coefficients between weed biomass \{dry weight of broadleaf, grasses and total weeds $\left.\left(\mathrm{g} / \mathrm{m}^{2}\right)\right\}$, faba bean seed yield and it's components were highly significant at $1 \%$ level during 2017/18 and 2018/19 seasons.
There were negative correlation coefficients between weed biomass (dry weight of broadleaf, dry weight of grasses and dry weight of total weeds) and seed yield/fed and yield components in both seasons.

Table 7. Correlation coefficients between dry weight of broad -leaved, grassy and total weeds, yield and yield components during 2017/18 and 2018/19 seasons.

\begin{tabular}{|c|c|c|c|c|c|c|c|c|c|c|c|}
\hline \multirow[b]{2}{*}{ Characters } & \multicolumn{3}{|c|}{ Dry weight $\left(\mathrm{g} / \mathrm{m}^{2}\right)$} & \multirow{2}{*}{$\begin{array}{c}\text { Leaf } \\
\text { area } \\
\text { index }\end{array}$} & \multirow{2}{*}{$\begin{array}{c}\text { Plant } \\
\text { height } \\
\text { cm) }\end{array}$} & \multirow{2}{*}{$\begin{array}{c}\text { No. of } \\
\text { branches } \\
\text { /plant }\end{array}$} & \multirow{2}{*}{$\begin{array}{c}\text { No. of } \\
\text { pods } \\
\text { /plant }\end{array}$} & \multirow{2}{*}{$\begin{array}{l}\text { No. of } \\
\text { seeds } \\
\text { /plant }\end{array}$} & \multirow{2}{*}{$\begin{array}{c}\text { Seed } \\
\text { weight } \\
\text { /plant } \\
\text { (g) }\end{array}$} & \multirow{2}{*}{$\begin{array}{c}100- \\
\text { seed } \\
\text { weight } \\
\text { (g) }\end{array}$} & \multirow{2}{*}{$\begin{array}{c}\text { Seed } \\
\text { yield } \\
\text { /fed } \\
(\mathbf{k g})\end{array}$} \\
\hline & $\begin{array}{l}\text { Broad- } \\
\text { leaved }\end{array}$ & $\begin{array}{c}\text { Grassy } \\
\text { weeds }\end{array}$ & $\begin{array}{r}\text { Total } \\
\text { weeds }\end{array}$ & & & & & & & & \\
\hline & \multicolumn{11}{|c|}{ 2017/18 season } \\
\hline Dry weight of broad-leaved weeds $\left(\mathrm{g} / \mathrm{m}^{2}\right)$ & 1 & & & & & & & & & & \\
\hline Dry weight of grassy weeds $\left(\mathrm{g} / \mathrm{m}^{2}\right)$ & $0.965^{* *}$ & 1 & & & & & & & & & \\
\hline Dry weight of total weeds $\left(\mathrm{g} / \mathrm{m}^{2}\right)$ & $0.995^{* *}$ & $0.986^{* *}$ & 1 & & & & & & & & \\
\hline Leaf area index & $-0.902^{* *}$ & $-0.863^{* *}$ & $-0.896^{* *}$ & 1 & & & & & & & \\
\hline Plant height cm) & $-0.848^{* *}$ & $-0.748^{* *}$ & $-0.818^{* *}$ & $0.956^{* *}$ & 1 & & & & & & \\
\hline No. of branches/plant & $-0.850^{* *}$ & $-0.750^{* *}$ & $-0.821^{* *}$ & $0.695^{* *}$ & $0.735^{* *}$ & 1 & & & & & \\
\hline No. of pods/plant & $-0.792^{* *}$ & $-0.690^{* *}$ & $-0.761^{* *}$ & $0.532^{*}$ & $0.574^{*}$ & $0.945^{* *}$ & 1 & & & & \\
\hline No. of seeds/plant & $-0.803^{* *}$ & $-0.683^{* *}$ & $-0.766^{* *}$ & $0.619^{* *}$ & $0.670^{* *}$ & $0.949^{* *}$ & $0.960^{* *}$ & 1 & & & \\
\hline Seed weight/plant (g) & $-0.839^{* *}$ & $-0.754^{* *}$ & $-0.815^{* *}$ & $0.603^{* *}$ & $0.623^{* *}$ & $0.965^{* *}$ & $0.985^{* *}$ & $0.970^{* *}$ & 1 & & \\
\hline 100-seed weight g) & $-0.861^{* *}$ & $-0.775^{* *}$ & $-0.837^{* *}$ & $0.667^{* *}$ & $0.682^{* *}$ & $0.966^{* *}$ & $0.944^{* *}$ & $0.947^{* *}$ & $0.969^{* *}$ & 1 & \\
\hline \multirow[t]{2}{*}{ Seed yield/fed $(\mathrm{kg})$} & $-0.930^{* *}$ & $-0.857^{* *}$ & $-0.911^{* *}$ & $0.927^{* *}$ & $0.922^{* *}$ & $0.843^{* *}$ & $0.739^{* *}$ & $0.840^{* *}$ & $0.803^{* *}$ & $0.834^{* *}$ & 1 \\
\hline & \multicolumn{11}{|c|}{ 2018/19 season } \\
\hline Dry weight of broad-leaved weeds $\left(\mathrm{g} / \mathrm{m}^{2}\right)$ & 1 & & & & & & & & & & \\
\hline Dry weight of grassy weeds $\left(\mathrm{g} / \mathrm{m}^{2}\right)$ & $0.944^{* *}$ & 1 & & & & & & & & & \\
\hline Dry weight of total weeds $\left(\mathrm{g} / \mathrm{m}^{2}\right)$ & $0.992^{* *}$ & $0.978^{* *}$ & 1 & & & & & & & & \\
\hline Leaf area index & $-0.897^{* *}$ & $-0.845^{* *}$ & $-0.889^{* *}$ & 1 & & & & & & & \\
\hline Plant height cm) & $-0.847^{* *}$ & $-0.711^{* *}$ & $-0.808^{* *}$ & $0.933^{* *}$ & 1 & & & & & & \\
\hline No. of branches/plant & $-0.882^{* *}$ & $-0.774^{* *}$ & $-0.853^{* *}$ & $0.661^{* *}$ & $0.704^{* *}$ & 1 & & & & & \\
\hline No. of pods/plant & $-0.754^{* *}$ & $-0.621^{* *}$ & $-0.715^{* *}$ & 0.458 & $0.552^{*}$ & $0.934^{* *}$ & 1 & & & & \\
\hline No. of seeds/plant & $-0.771^{* *}$ & $-0.643^{* *}$ & $-0.734^{* *}$ & $0.485^{*}$ & $0.568^{*}$ & $0.932^{* *}$ & $0.983^{* *}$ & 1 & & & \\
\hline Seed weight/plant (g) & $-0.826^{* *}$ & $-0.724^{* *}$ & $-0.799^{* *}$ & $0.530^{*}$ & $0.577^{*}$ & $0.961^{* *}$ & $0.975^{* *}$ & $0.981^{* *}$ & 1 & & \\
\hline 100-seed weight g) & $-0.937^{* *}$ & $-0.859^{* *}$ & $-0.920^{* *}$ & $0.757^{* *}$ & $0.743^{* *}$ & $0.964^{* *}$ & $0.863^{* *}$ & $0.894^{* *}$ & $0.927^{* *}$ & 1 & \\
\hline Seed yield/fed (kg) & $-0.931^{* *}$ & $-0.823^{* *}$ & $-0.903^{* *}$ & $0.887^{* *}$ & $0.937^{* *}$ & $0.849^{* *}$ & $0.759^{* *}$ & $0.779^{* *}$ & $0.784^{* *}$ & $0.879^{* *}$ & 1 \\
\hline
\end{tabular}

\section{C - Herbicide residues in faba bean seeds.}

Data in Table 8 and Figs (1-10) demonstrate that the stability of the three herbicides as post sowing and before planting irrigation (acetochlor, pendimethalin and metribuzin) and two herbicides as post emergence (bentazon) and (clethodium). The residues levels of the five herbicides were rapidly degraded in open field by sunlight, many species of microorganisms and different levels of acidity and alkalinity in the soil. So, the residues of faba bean seeds were less than the allowable level according to European Food Safety Authority (EFSA, 2012).

Table 8. Residues for acetochlor, pendimethalin, metribuzin, bentazon and clethodium in seeds of faba bean in 2018/19 season.

\begin{tabular}{lccc}
\hline \multicolumn{1}{c}{ Herbicide } & $\begin{array}{c}\text { Rate of } \\
\text { active ingredient }(\mathbf{g} / \mathbf{f e d})\end{array}$ & $\begin{array}{c}\text { Residual in faba bean } \\
\text { seeds } \\
(\mathbf{m g} / \mathbf{~ k g})\end{array}$ & $\begin{array}{c}\text { Maximum allowable } \\
\text { residues level } \\
(\mathbf{m g} / \mathbf{~ k g})\end{array}$ \\
\hline Acetochlor & 840 & $\mathrm{ND}$ & 0.01 \\
Pendimethalin & 773.5 & $\mathrm{ND}$ & 0.05 \\
Metribuzin & 210 & $\mathrm{ND}$ & 0.1 \\
Bentazon & 120 & $\mathrm{ND}$ & 0.3 \\
Clethodium & 62.5 & $\mathrm{ND}$ & 0.5 \\
\hline
\end{tabular}

* No detected 


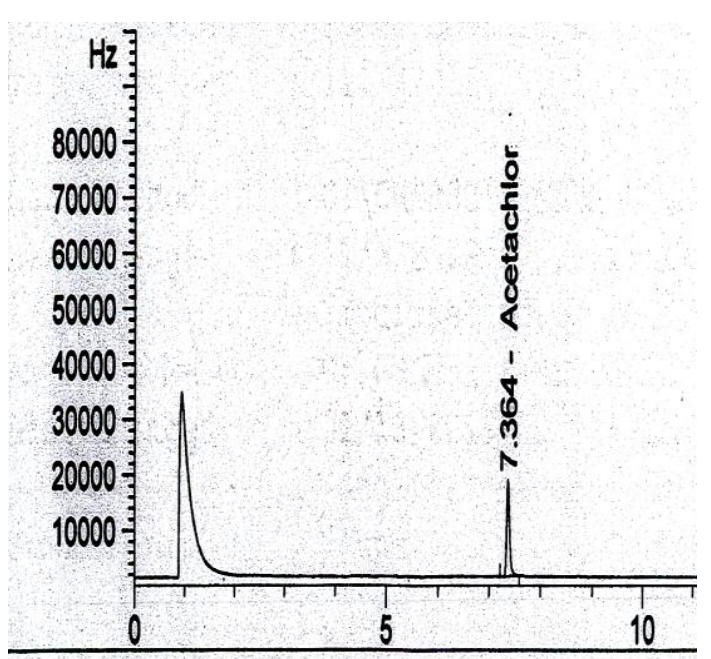

Fig (1)

Chromatogram of standard of acetochlor (Harness $84 \%$ EC)

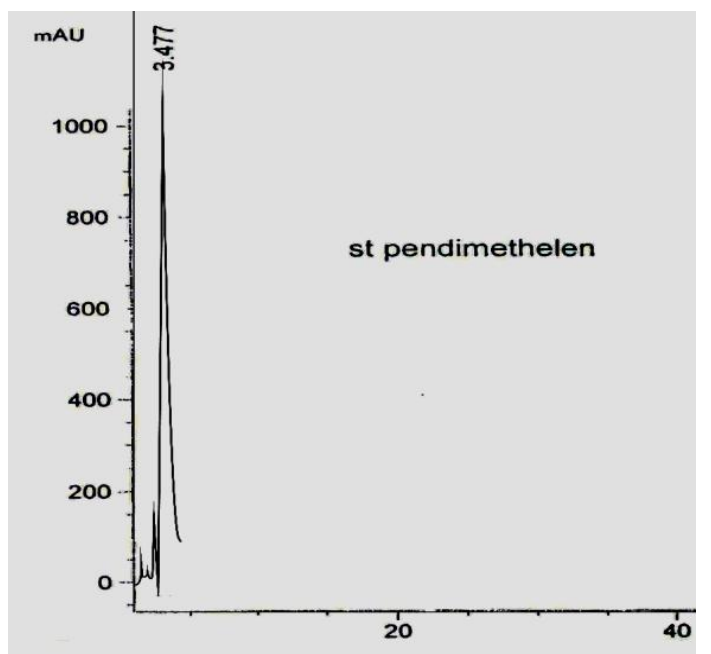

Fig (3)

Chromatogram of standard of pendimethalin (Stomp extra $45.5 \% \mathrm{CS}$ )

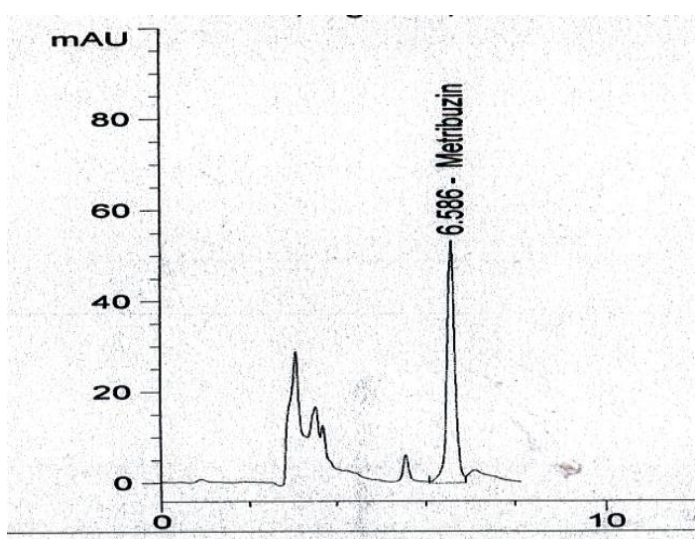

Fig (5)

Chromatogram of standard of metribuzin (Sencor $70 \% \mathrm{WP}$ )

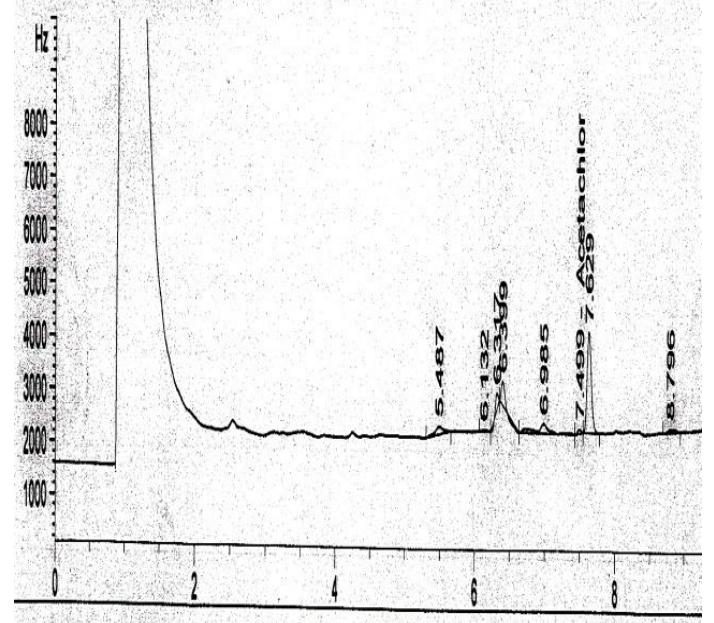

Fig (2)

Chromatogram of sample acetochlor (Harness $84 \%$ EC) at $840 \mathrm{~g} \mathrm{a}$.i/fed in faba been seeds

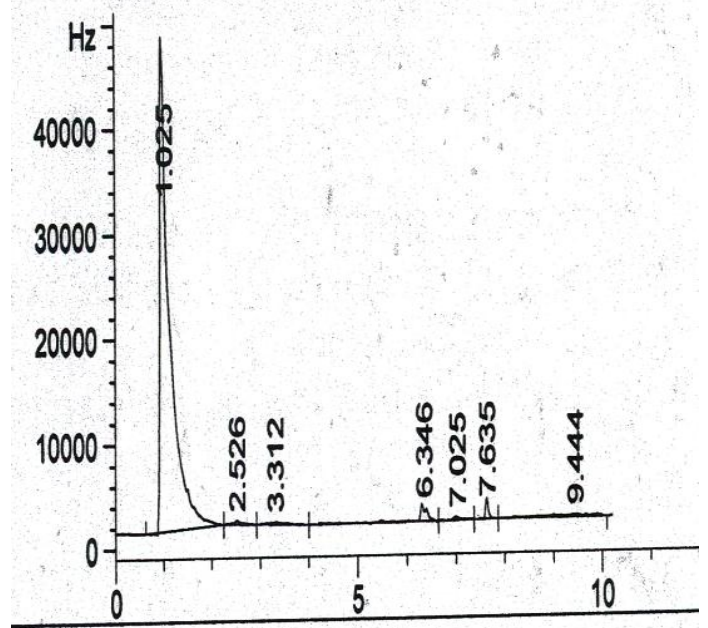

Fig (4)

Chromatogram of sample pendimethalin (Stomp extra $45.5 \% \mathrm{CS}$ ) at $773 \mathrm{~g}$ a.i/fed in faba been seeds

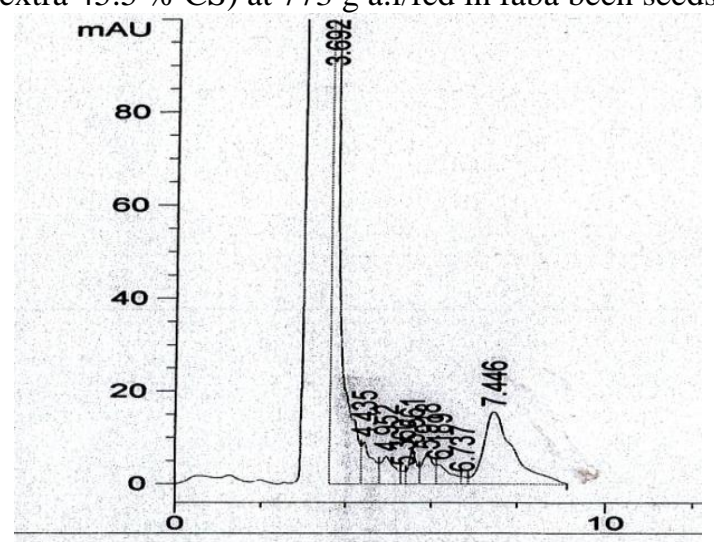

Fig (6)

Chromatogram of sample metribuzin (Sencor $70 \%$ WP) at $210 \mathrm{~g}$ a.i/fed faba in been seeds 


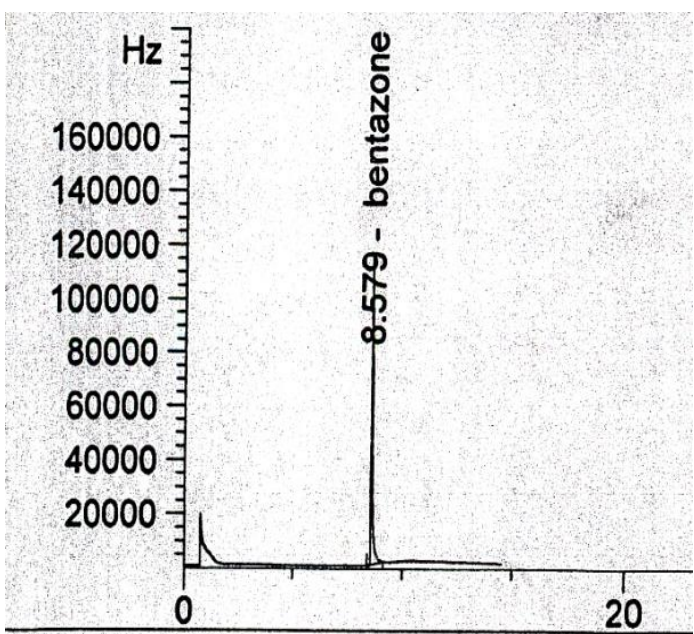

Fig (7)

Chromatogram of standard of bentazon (Basagran $48 \%$ AS)

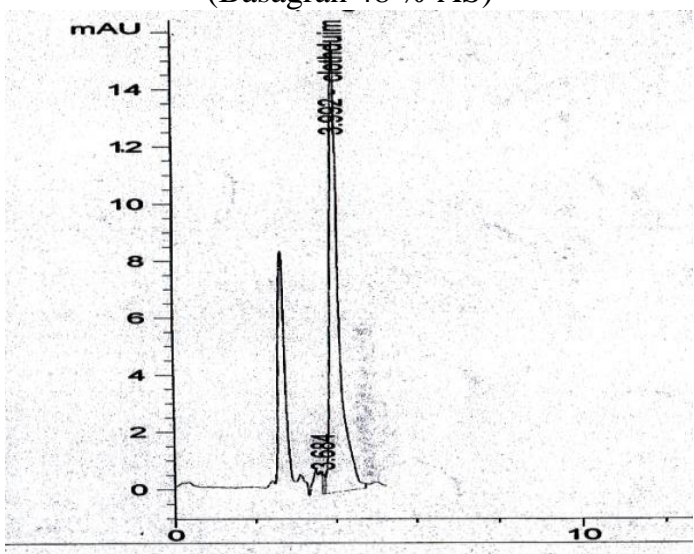

Fig (9)

Chromatogram of standard of clethodium (Select super $12.5 \%$ EC)

\section{D - Economic evaluation:}

Total fixed costs including values of production inputs such as land rent, soil preparation, plant sowing, fertilizers, irrigation, insect control, harvesting and other miscellaneous costs were 8840 and 8975.6 L.E. in the first and second seasons, respectively. The price of one kilogram seeds (Giza 843) was 25.00 and 27.00 L.E. in the first and second seasons, respectively. Decreasing distances from 30 to 25 and $20 \mathrm{~cm}$ between hills increased seed rates from 56.00 to 67.20 and $86.00 \mathrm{~kg} / \mathrm{fed}$, respectively. The costs of price herbicides and the spraying were 320.00 and 340.00 L.E. (acetochlor), 315.00 and 325.00 L.E. (pendimethalin), (230.00 and 240.00 L.E. (metribuzin) and 600.00 and 620.00 L.E. (bentazon + clethodium) as well as the cost of hand hoeing twice was 900.00 and 1200.00 L.E. in the first and second seasons, respectively.

Data in Table 9 show that the total costs of faba bean production/fed as affected by the applied different treatments (average of 2017/18 and 2018/19 seasons). From such data, it is clear that the minimum total costs were obtained with faba

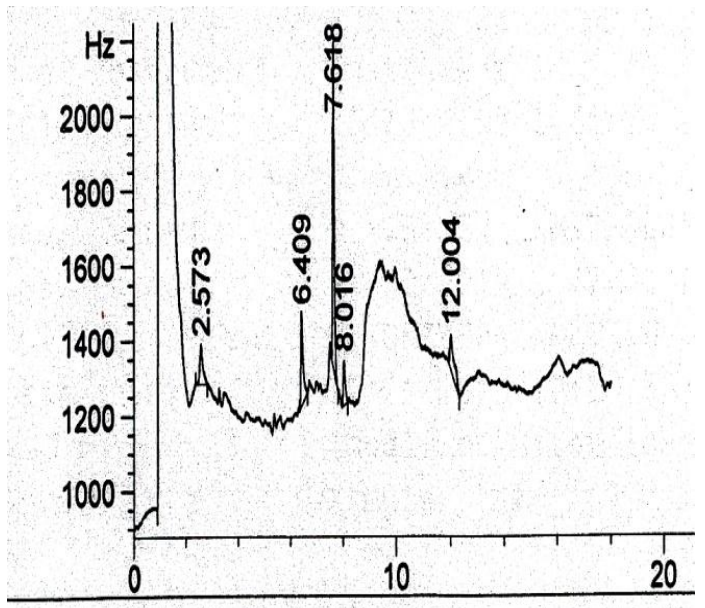

Fig (8)

Chromatogram of sample bentazon (Basagran $48 \%$

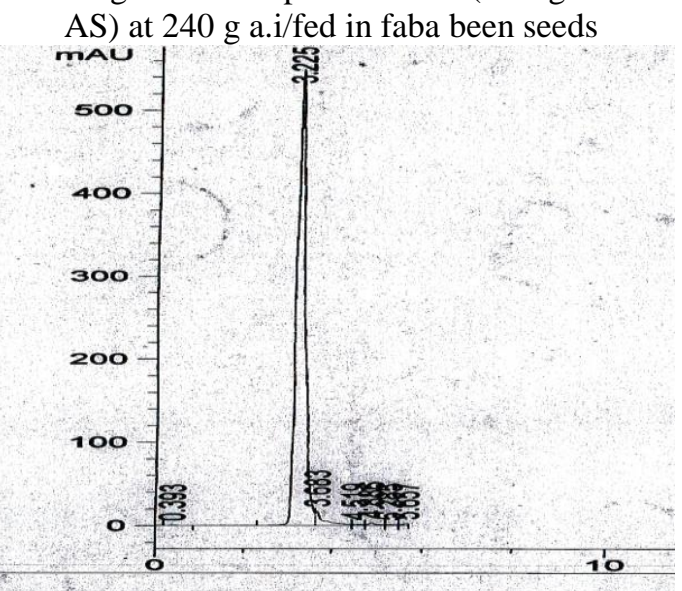

Fig (10)

Chromatogram of sample clethodium (Select super $12.5 \% \mathrm{EC}$ ) at $62.5 \mathrm{~g}$ a.i/fed in faba been seeds

bean planting at wide distance between hills (30 $\mathrm{cm})$ and unweeded check, being 10240 and 10488 L.E, respectively, and the maximum total costs were obtained from planting faba bean at narrow distance between hills $(20 \mathrm{~cm})$ and mechanical weed control by hand hoeing twice being 11890 and 12498 L.E./fed respectively.

The gross income of faba bean seed yield in L.E./fed as affected by the applied different treatments in both seasons presented in Table (9). In this estimation the price of faba bean was 2250 and 2500 L.E./ton in the both seasons, respectively, as given by Extension service information. From such results, it is clear that the highest gross income of seed yield/fed were detected with planting faba bean at narrow distance between hills $(20 \mathrm{~cm})$ with mechanical weed control by hand hoeing twice which were 22325 and 20963 L.E./fed in first and second seasons, respectively. On the other hand, the lowest values of seed yield/fed were obtained from faba bean planting at $30 \mathrm{~cm}$ between hills under unweed check which were 4775 and 3235 L.E./fed in the first and second seasons, respectively, with reduction of 17550 and 17728 L.E. or 78.61 and 
$84.57 \%$ compared with the highest treatment in the first and second seasons, respectively.

Results in Table 9 reveal that the highest net benefit was achieved from faba bean planting at 20 $\mathrm{cm}$ between hills and weed control by hand hoeing twice which were 10435 and 8465 L.E./fed making a $\mathrm{B} / \mathrm{C}$ ratio of 1.88 and $1.68 \%$ in the first and second seasons, respectively. On the other hand, the lowest net benefit were -5466 and -7253 L.E./fed with the lowest $\mathrm{B} / \mathrm{C}$ ratio of 0.47 and $0.31 \%$ which were recorded by faba bean planting at wide distance between hills $(30 \mathrm{~cm})$ with no management to weed control in $2017 / 18$ and $2018 / 19$ seasons, respectively.

Table 9. Determination economic for the interaction between planting distances and weed control treatments during 2017/18 and 2018/19 seasons.

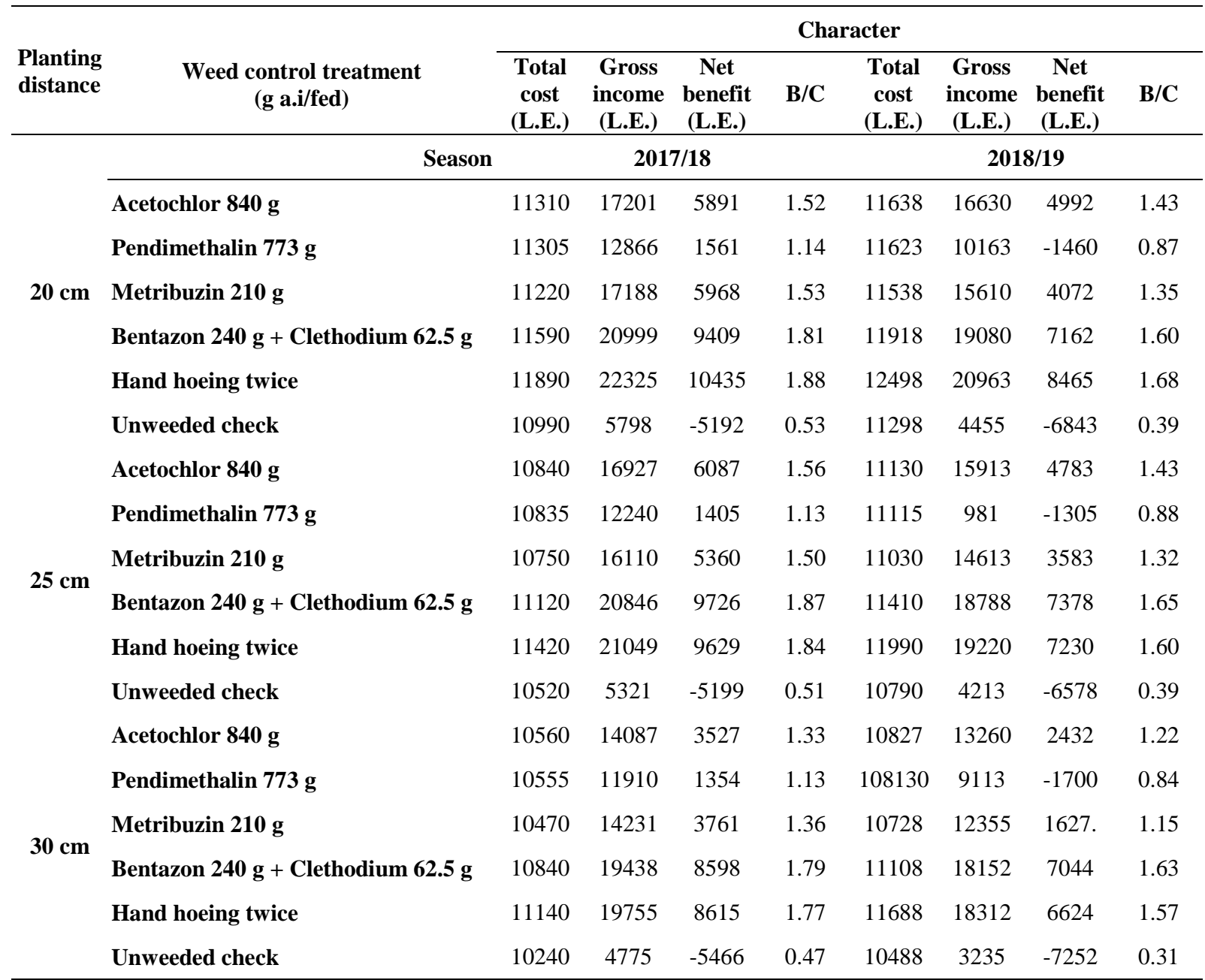

\section{Conclusion}

Results of this work demonstrated that faba bean performs better with the interaction between either at narrow distance between hills $(20 \mathrm{~cm})$ and hand hoeing twice or bentazon $240 \mathrm{~g}$ a.i/fed + clethodium $62.5 \mathrm{~g}$ a.i/fed. which gave the lowest values of weed biomass as well as produced the greatest values of seed yield/fed during both seasons, and be recommended to solve broadleaved and grassy weeds problems through the first half life period of in faba bean residues. Furthermore, the above weed control treatments gave the highest values of gross income and net benefit.

\section{References}

Abd El-Rahman, R. A. M. (2014). Effect of plant population and distribution on yield and yield components of five faba bean genotypes. J. Plant Prod. Mansoura Univ., 5 (11): 1965-1972.

Abd El-Razik, M. A. (2006). Effect of some weed control treatments on growth, yield and yield components and some seed technological characters and associated weeds of faba bean plants. J. Agric. Sci., 31 (10): 6283-6292.

Abou-El-Seba, S. E. A.; A. M. Abou-Salama; G. R. El-Nagar and M. A. El-Mohsen (2016). Physiological responses for growth and yield of some faba bean varieties under different plant densities. Assiut J. Agric. Sci., 47 (6-1): 18-33. 
Agegnehu, G. and R. Fessehaie (2006). Response of faba bean to phosphate fertilizer and weed control on Nitisols of Ethiopian highlands. Ital. J. Agron. Riv. Agron., (2): 281-290.

Aldhahi, H. H. K.; H. I. Almtarfi and A. J. AlSarraji (2018). Evaluation of the effect of some herbicides on Vicia faba, L. growth traits. J. Res. Ecol., 6 (2): 1808-1813.

Alemu, N. and J. Sharma (2018). Assessment of integrated weed management practices on weed dynamics, yield components and yield of faba bean (Vicia faba, L.) in Eastern Ethiopia. Turkish J. Agric. Food Sci. \& Tech., 6 (5): 570580.

Alizadeh, F. G.; N. Aryannia and S. Lorzadeh (2014). To study the effects of cultivar, plant density and weed control on number of weeds in farm of faba bean in climatic conditions of Khuzestan. WALIA J., 30 (S1): 363-370.

Al-Suhaibani, N.; S. El-Hendawy and U. Schmidhalter (2013). Influence of varied plant density on growth, yield and economic return of drip irrigated faba bean (Vicia faba, L.). Turkish J. Field Crops, 18 (2): 185-197.

Bakry, B. A.; T. A. Elewa; M. F. El karamany; M. S. Zeidan and M. M. Tawfik (2011). Effect of row spacing on yield and its components of some faba bean varieties under newly reclaimed sandy soil condition. World J. Agric. Sci., 7 (1): 68-72.

Black, C. A. and D. D. Evans (1965). Methods of Soil Analysis. Amer. Soc. of Agron., Inc. Pub. Madison, Wisconsin, USA.

Dahmardeh, M.; M. Ramroodi and J. Valizadeh (2010). Effect of plant density and cultivars on growth, yield and yield components of faba bean (Vicia faba, L.). African J. Biotechnol., 9 (50): 8643-8647.

Derogar, N. and M. Mojaddam (2014). Effect of plant density on grain yield and yield components in faba bean. Inter. J. Plant Animal \& Environ. Sci., 4 (2): 92-96.

El-Metwally, I. M. (2016). Efficiency of some weed control treatments and some biostimulants on growth, yield and its components of faba bean and associated weeds. Int. J. Pharm. Tech. Res., 9 (12):165-174.

El-Metwally, I. M. and M. G. Dawood (2016). Response of faba bean plants to weed control treatments and foliar spraying of some biostimulants under sandy soil condition. Int. J. Pharm Tech. Res., 9 (12):155- 64.
El-Metwally, I. M. and M.T. Abdelhamid (2008). Weed control under integrated nutrient management systems in Faba bean (Vicia faba, L.) production in Egypt. Plant Daninha, 26 (3): 585-594.

El-Metwally, I. M.; W. A. E. Abido and R. M. H. Tagour (2017). Influence of plant population and weed control treatments on associated weeds, growth, yield and quality of faba bean. J. Plant Production, Mansoura Univ., 8 (10): 983991.

European Food Safety Authority (EFSA), Parma, Italy (2012). Reasoned faba bean on the review of the existing maximum residue levels (MRLs) for pendimethalin according to Article 12 of Regulation (EC) No 396/2005. EFSA J., 10: 4, 2683.

Fakkar, A. A. O. and Y. A. M. Khlifa (2018). Effect of corps rotation and sequence weed control treatments on weeds and faba bean productivity. Egypt. J. Agron., 40 (2): 181-192.

Freed R. D. (1991). MSTATC Microcomputer Statistical Program. Michigan State University, East Lansing, Michigan, USA.

Gomez, K. A., and A. A. Gomez (1984). Statistical Procedures for Agricultural Research. $2^{\text {nd }}$, (ed). John Wiley and Sons, NY, U.S.A.

Heady, E. O. and J. L. Dillon (1961).Agricultural production functions. Library of congress catalog card number: 60 - 11128, Iowa State University press.

Kavurmaci, Z.; U. Karadavut; K. Kökten and A. Bakoğlu (2010). Determining critical period of weed-crop competition in faba bean (Vicia faba, L.). Int. J. Agric. Biol., 12 (2): 318-320.

Khalil, S. K.; A. W. Amanullah and A. Z. Khan (2011). Variation in leaf traits, yield and yield components of faba bean in response to planting dates and densities. Egypt. Acad. J. Biolog. Sci., 2 (1): 35-43.

Nguyen, T. D.; E. M. Han; M. S. Seo; S. R. Kim; M. Y. Yun; D. M. Lee and G. H. Lee (2008). A multi-residue method for the determination of 203 pesticides in rice paddies using gas chromatography/mass spectrometry. Analytica Chemical Acta., 619: 67-74.

Roads, F. M. and M. E. Bloodwoath (1964). Area measurement of cotton leaves by dry weight method. Agron. J., 56 (5).

Yucel, D. O. (2013). Optimal intra-row spacing for production of local faba bean (Vicia faba, L. major) cultivars in the Mediterranean conditions. Pak. J. Bot., 45 (6): 1933-1938. 


\section{تأثير مساقات الزراعة و معاملات مقاومة الحشائش على محصول الفول البلدي و الحشائش المصاحبة ** * السعيد محمد محمود الجدوي * أثرف محمد فضل الله* * أحمد مصطفى أحمد حسانين "قسم المحاصيل ـ كلية الزراعة . جامعة بنها ـ مصر .

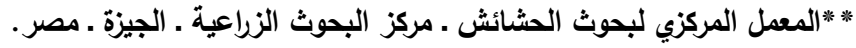

Corresponding author: alsaeed.algedwy@fagr.bu.edu.eg

أجريت تجربتان حقليتان في مزرعة مركز البحوث والتجارب الزراعية بكلية الزراعة بمشتهر جامعة بنها (مركز طوخ - محافظة

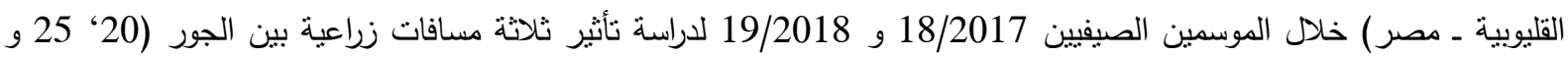
30 سم) وستة معاملات لمقاومة الحشائش وهي أسينوكلور 840 جم مادة فعالة/فدان (هارنس 84 \%)؛ بينديميثالين 773.5 جم مادة فعالة/فدان (ستومب 45.5 \%) ' ميتريبيوزين 210 جم مادة فعالة/فدان (سنكور 70 \%) ؛ بنتازون 240 جم مادة فعالة/فدان (بازجران

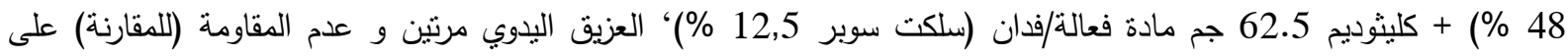

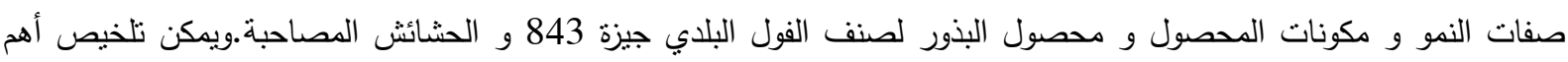
النتائج فيما يلي:. أعطت نبانات الفول البلدي المنزرعة على أضيق مسافة (20 سم بين الجور) أفضل تأثثر في نقليل الوزن الجاف للحشائش

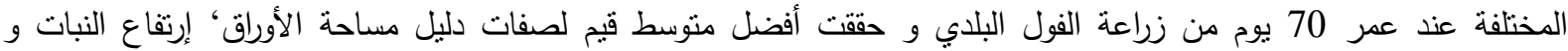

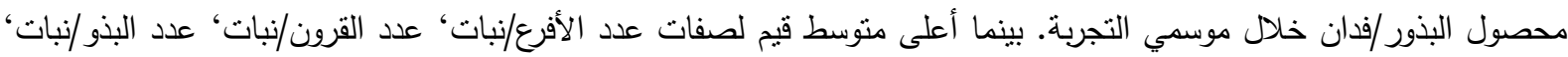
وزن البذور/نبات و دليل البذرة تم الحصول عليها من زراعة نباتات الفول البلدي على أوسع مسافات (30 سم بين الجور) خلال موسمي التجربة. أثنارت النتائج أن الوزن الجاف الكلي للحشائش الحولية المنتشرة في حقول الذرة الثشامية تحت معاملة بدون مقاومة (كنترول) كان 659.9 و 1041.8 كجم وأحدث نقص في محصول بذور الفول البلدي بمقدار 74.82 و 79.65 \% مقارناً بأفضل معاملة لمقاومة الحشائش (العزيق اليدوي مرتين) خلال موسمي التجربة على الترتيب. كما أوضحت النتائج أن إجراء العزيق اليدوي مرتين و إستخدام

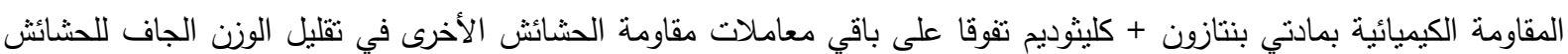

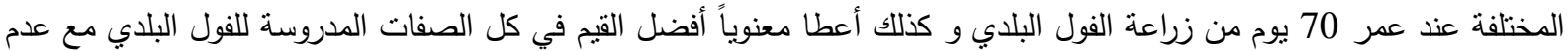

وجود فروق معنوية بينهما خلال موسمي التجربة.

أثنارت النتائج أن أفضل تأثثر في نقليل الوزن الجاف للحشائش المختلفة تحقق من زراعة نباتات الفول البلدي بأضيق مسافة (20)

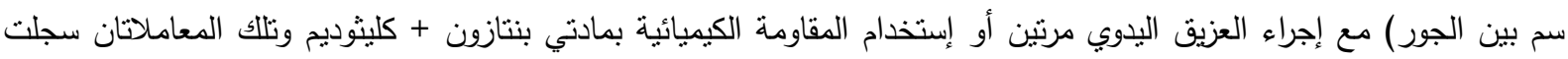
أفضل متوسط لقيم إرتفاع النبات و محصول البذور/فدان خلال موسمي التجربة. بينما أعلى متوسط قيم لصفات عدد القرون/نبات،

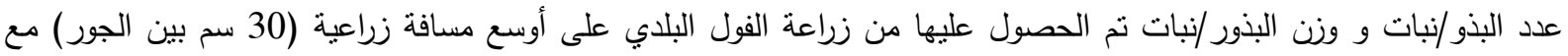

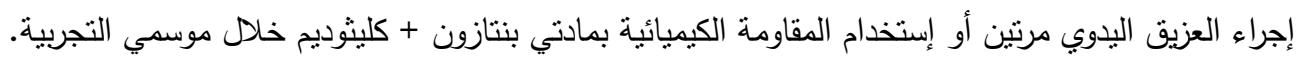

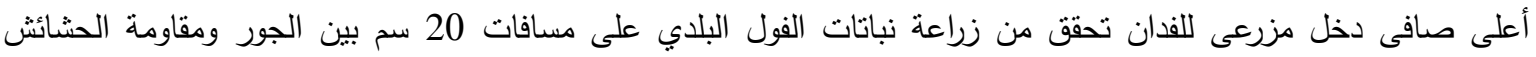
بالعزيق اليدوي مرتين حيث بلغ 10435 جنية و 8465 جنية/فدان دون وجود اى متنقيات للمبيدات تحت الدراسة فى بذور الفول خلال موسمى الزراعة على التوالى . توصي النتائج بزراعة صنف الفول البلدي جيزة 843 على مسافة 20 سم بين الجور مع إجراء العزيق اليدوي مرنين أو إستخدام

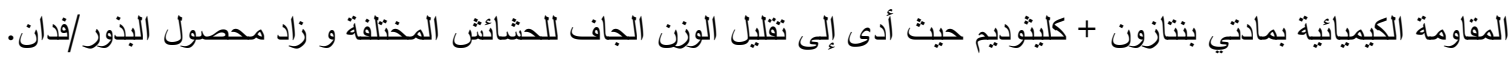

